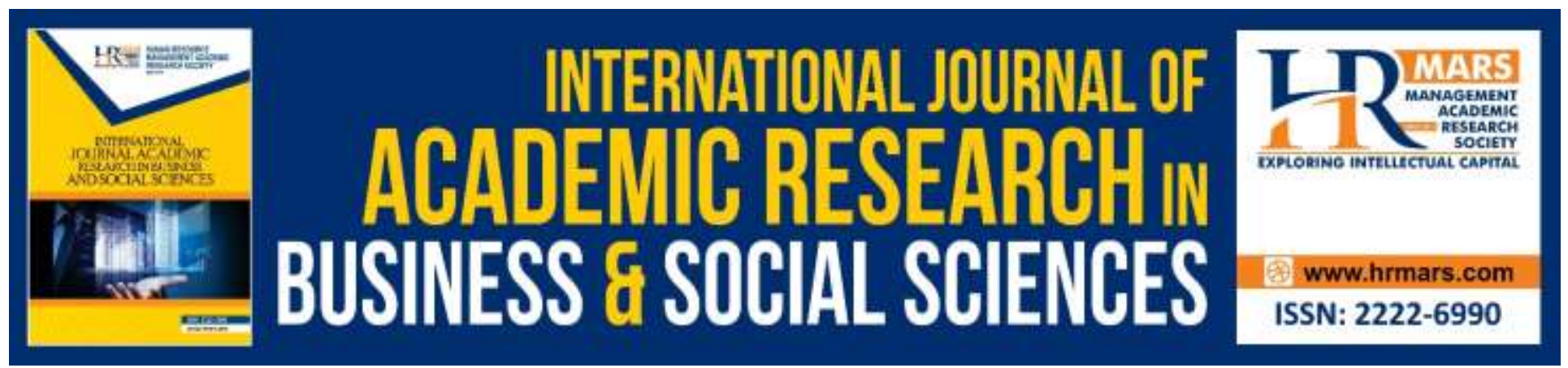

\title{
The Effect of Service and Food Quality on Customer Satisfaction in Indonesian Train Catering
}

Ika Ratna Palupi, Nur Arief Darmawan, Yeni Prawiningdyah

To Link this Article: http://dx.doi.org/10.6007/IJARBSS/v10-i13/6891 DOI:10.6007/IJARBSS/v10-i13/6891

Received: 22 December 2019, Revised: 07 January 2020, Accepted: 22 January 2020

Published Online: 13 February 2020

In-Text Citation: (Palupi et al., 2020)

To Cite this Article: Palupi, I. R., Darmawan, N. A., \& Prawiningdyah, Y. (2020). The Effect of Service and Food Quality on Customer Satisfaction in Indonesian Train Catering. International Journal of Academic Research in Business and Social Sciences, 10(13), 88-97.

Copyright: (c) 2020 The Author(s)

Published by Human Resource Management Academic Research Society (www.hrmars.com)

This article is published under the Creative Commons Attribution (CC BY 4.0) license. Anyone may reproduce, distribute, translate and create derivative works of this article (for both commercial and non-commercial purposes), subject to full attribution to the original publication and authors. The full terms of this license may be seen at: http://creativecommons.org/licences/by/4.0/legalcode

Special Issue: Upstream Research in Business and Management: Towards Socio-Economic Prosperity, 2020, Pg. 88 - 97 http://hrmars.com/index.php/pages/detail/IJARBSS JOURNAL HOMEPAGE

Full Terms \& Conditions of access and use can be found at http://hrmars.com/index.php/pages/detail/publication-ethics 


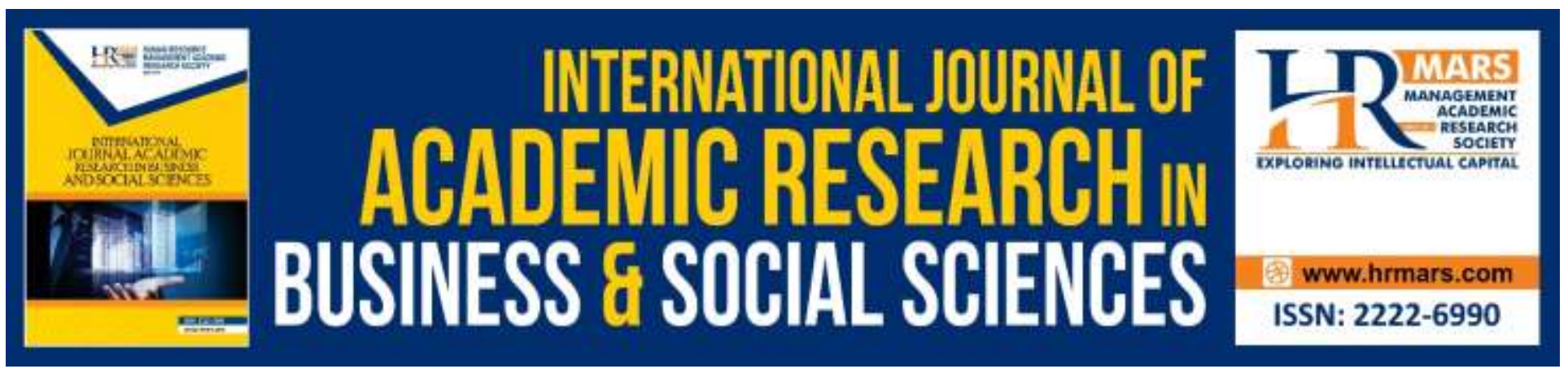

\title{
The Effect of Service and Food Quality on Customer Satisfaction in Indonesian Train Catering
}

\author{
Ika Ratna Palupi ${ }^{1}$, Nur Arief Darmawan ${ }^{1}$, Yeni Prawiningdyah² \\ ${ }^{1}$ Department of Nutrition and Health, Faculty of Medicine, Public Health and Nursing Universitas \\ Gadjah Mada Yogyakarta, ${ }^{2}$ Committee of Quality and Patient Safety, Dr. Sardjito General Hospital, \\ Yogyakarta \\ Email: ikaratna@ugm.ac.id
}

\begin{abstract}
Foodservice industry has broadened to multiple settings including public transportation service. The on board service and food may affect people's travel experience, yet studies pertaining to customer satisfaction of foodservice operations in railway setting are limited. This study aimed to evaluate the effect of service and food quality on customer satisfaction in Indonesian train catering. A total of 83 consumers in long-distance passengers' trains of Jakarta and Yogyakarta relations in Java region were surveyed for their perceived service quality, food quality and overall satisfaction of the foods delivered at seat. Data collection was carried out through a validated questionnaire in online format. Bivariate and multivariate statistical test were employed to analyze the data. This study suggested that overall service quality had positive correlation with customer satisfaction in railway foodservice $(r=0.304, p<0.01)$ and so did overall food quality $(r=0.395, p<0.01)$. It was also shown that service and food quality simultaneously explained approximately $17.8 \%$ of the variability of customer satisfaction $\left(R^{2}=0.178\right)$. The main aspect of service and food quality which influenced customer satisfaction were meal presentation $(p<0.05)$. This study implied the positive effect of service and food quality on customer satisfaction in train catering.

Keywords: Customer Satisfaction, Service Quality, Food Quality, Train Catering, Foodservice, Railway
\end{abstract}

\section{Introduction}

Railway transport is one of the modes of transportation that is popular due to its ability to carry passengers and goods in large quantities at fairly short travel time without any obstacles in its path. These days, railway business is growing rapidly in Indonesia as indicated by increased number of railway passengers of $14.85 \%$ annually since 2012, mainly in the Java region (BPS-Statistics Indonesia, 2016). The quality of passenger services is one of the railway operator's main concerns (Nathanail, 2008). A study in Indian railway transport setting reported that basic facilities, safety and security of passengers, cleanliness in trains, and the availability of food services for passengers during 
the trip were the main determinants of passenger satisfaction on the quality of public services provided (Sheeba \& Kumuthadevi, 2013; Omar, Rahman, Hamid, 2018).

The onboard services and food are the most remembered feature of people's travel experience, therefore the food service offered to passengers remains an essential part in overall service experience (Jones, 2007). Good-quality foods on a journey is expected as well as appreciated by travellers, moreover in a long-distance journey where passenger's needs in provision of ready meals become greater (Briginshaw, 2013). Train catering has its strength in that passengers have the ability to take pleasure in a tasty meal on the move unlike airline service which has to deal with altitude affecting sensory abilities (Jones, 2007). Food and beverages also appear as an important post-purchase factor in a transportation mode for consumers although it may not influence their prepurchase decisions. Oliver (1980) argued that changes between attitudes formed at the pre purchasing and post purchasing point is mediated by satisfaction.

Customer satisfaction is defined as the feeling of well-being and pleasure resulted from attaining what an individual expects from a desirable product and/ or service (WTO, 1985). It is a main factor required to generate and sustain a competitive business (Ueltschy et al, 2002) and is affected by service quality (Bei and Chiao, 2001). Several studies carried out in Europe and Asia context have confirmed that food restoration services during the journey are part of the company's marketing competitiveness to passengers (Frapin-Beaugé et al., 1994; James, 2005; Jones, 1995; Law \& Leung, 2000). Study on the impact of the in-flight service quality on airline customer satisfaction revealed that presentation style of food and food quality were among the six important service quality factors in the prestige class while food quality was shown as one of five important service quality factors in the economy class (An and Noh, 2009).

Consumer evaluation studies on the food quality in food service operations generally include tangible attributes such as food presentation, flavor, freshness and temperature. In addition, the consumer will assess how well service attributes such as reliability, quality assurance, empathy and responsiveness provided by the employees (Josiam et al., 2014; Zakaria, \& Abdullah, 2018). As such, a number of studies have investigated subjects related to customer satisfaction in transportation food service, mainly the in-flight catering, yet there have been limited studies performed on foodservice in railway settings. This study aimed to evaluate the effect of service and food quality on customer satisfaction in Indonesian long-distance train catering.

\section{Method}

In order to evaluate the quality and satisfaction perceived by passengers, a consumer survey was undertaken in March 2016 on two long-distance passengers' trains in Java region, Indonesia. Both trains were that of Jakarta and Yogyakarta relation (departing from Jakarta to destination of Yogyakarta and vice versa) which provided only economy class seats and had a high average number of daily passengers (250-350 passengers per day).

The sample size was determined using the formula below (Lemeshow et al, 2007; Dimitra, 2014):

$$
n=\frac{\left(\left(Z_{(1-\alpha) / 2}\right)^{2} P(1-P) N\right)}{\left(d^{2}(N-1)+Z^{2}(1-\alpha) / 2 P(1-P)\right)}
$$


INTERNATIONAL JOURNAL OF ACADEMIC RESEARCH IN BUSINESS AND SOCIAL SCIENCES

Vol. 10, No. 13, Special Issue: Upstream Research in Business and Management: Towards Socio-Economic Prosperity. 2020, E-ISSN: 2222-6990 @ 2020 HRMARS

Using the desired $\alpha$ value of $0.05(Z \alpha=1.96)$, the number of consumer population $(N)$ was based on Product Sales Report data in the previous month of 204 passengers, the proportion of patient satisfaction in food service (P) was assumed to be $50 \%(0.5)$ and precision (d) was 0.1 , it was estimated that the number of sample needed was at least 66 passengers. A total of 83 passengers participated in this study and matched the inclusion criteria of subjects i.e. aged at least 12 years old, signing informed consent form, buying and consuming meal from the train catering menu that was delivered at passenger's seat. Subjects were recruited through purposive sampling.

In this study, we employed a quantitative method using cross-sectional design. Independent variables were service quality that included delivery time (DT), price (P) and cleanliness of the foods and eating utensils (C), and food quality that included taste (T), meal presentation (PT) and portion size (S). These indicators referred to previous study by Sheeba \& Kumuthadevi (2013) which observed positive correlation with consumer satisfaction, measured with 4-point likert scale ranging from totally disagree to totally agree. Dependent variable was the overall satisfaction of passengers towards foodservice measured with 5-point scale ranging from totally unsatisfied to totally satisfied. Instrument for data collection was an online-based questionnaire consisted of 8 items and presented to participants in mobile devices (smartphone). The questionnaire was developed by the researchers and then approved by the railway company. Six items in the questionnaire was constructed to measure every indicator of the food and service quality while 2 items corresponded with costumer's satisfaction. The questionnaire was tested for validity in 39 passengers with similar characteristics as the samples and declared as valid $(r>0.3081)$ as well as reliable (Cronbach's Alpha $=0.379)$. This study had obtained ethical clearance from the Medical and Health Research Ethics Committee of Faculty of Medicine Universitas Gadjah Mada.

Descriptive analysis was done to provide an overview on characteristics of the participants and levels of service and food quality. Data was computed and analyzed using SPSS version 19.0. To investigate the correlation between independent and dependent variables which were not normally distributed, bivariate analyzes of Spearman correlation test was performed at the significance level of 0.05 . To analyze the effect of independent factors simultaneously toward dependent variable, a multivariate analysis of multiple linear regression was employed.

\section{Results and Discussion Characteristics of Subjects}

Of the 83 passengers participated as subjects, $89.92 \%$ of which were adults (Table 1 ). Most subjects (47\%) ordered menu namely fried rice (Nasi Goreng Parahyangan), $21.7 \%$ had Balado chicken rice (Nasi Ayam Balado), 16.9\% had mixed rice (Nasi Rames Nusantara), 12.0\% had fried chicken and $2.4 \%$ had fried noodle (mee goreng). 
Table 1. Characteristics of Subjects

\begin{tabular}{lc}
\hline Characteristics & $\mathrm{n}(\%)$ \\
\hline Sex & \\
$\quad$ Male & $44(53.0)$ \\
$\quad$ Female & $39(47.0)$ \\
Age & \\
$\quad 12-17$ years & $6(7.2)$ \\
$\quad 18-59$ years & $74(89.2)$ \\
$\geq 60$ years & $3(3.6)$ \\
Educational level & \\
Low ${ }^{1}$ & $7(8.4)$ \\
$\quad$ Middle & $31(37.3)$ \\
High & \\
Income level* & $45(54.3)$ \\
Low (<IDR 1,500,000) & \\
Middle (IDR 1,500,000-2,500,000) & $21(25.3)$ \\
$\quad$ Upper-Middle (IDR 2,500,000-3,500,000) & $16(19.3)$ \\
High (> IDR 3,500,000) & $24(28.9)$ \\
\hline
\end{tabular}

${ }^{1}$ primary education and lower secondary education; ${ }^{2}$ upper secondary education; ${ }^{3}$ college/ university degree

* in Indonesian currency; IDR = Indonesian Rupiah

\section{Perceived Service Quality, Food Quality and Customer Satisfaction Level}

The average score of overall service quality aspects was 8.33 (Standard Deviation/SD of 1.083) while overall food quality score was 8.23 ( $S D=1.051)$. For each aspect, score of $\geq 3.00$ was classified as good whereas score $<3.00$ was classified as poor (Figure 1).

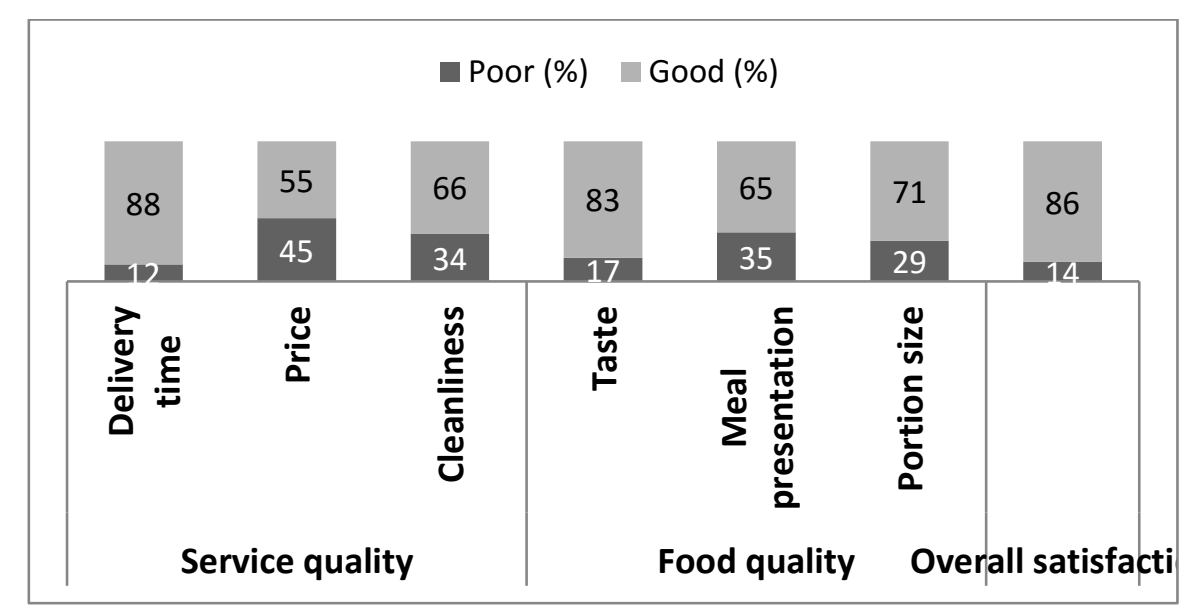

Fig. 1: Perceived Service quality, Food Quality and Customer Satisfaction Level 
INTERNATIONAL JOURNAL OF ACADEMIC RESEARCH IN BUSINESS AND SOCIAL SCIENCES

Vol. 10, No. 13, Special Issue: Upstream Research in Business and Management: Towards Socio-Economic Prosperity. 2020, E-ISSN: 2222-6990 @ 2020 HRMARS

\section{Correlations between Service and Food Quality with Overall Foodservice Satisfaction}

Bivariate analyses of Spearman correlation to test the relationships between independent and dependent variables are displayed in Table 2.

Table 2. Correlations between Service and Food Quality with Overall Foodservice Satisfaction

\begin{tabular}{lcc}
\multirow{2}{*}{ Quality Aspect } & \multicolumn{2}{c}{ Overall Foodservice Satisfaction } \\
\cline { 2 - 3 } & $\mathrm{r}$ & $\mathrm{p}$-value \\
\hline Service quality & 0.304 & $0.001^{*}$ \\
Delivery time & 0.004 & 0.752 \\
Price & 0.257 & $0.001^{*}$ \\
Cleanliness & 0.133 & $0.001^{*}$ \\
\hline Food quality & 0.395 & $0.001^{*}$ \\
Taste & 0.244 & $0.001^{*}$ \\
Meal presentation & 0.261 & $0.001^{*}$ \\
Portion size & 0.211 & $0.001^{*}$ \\
\hline$r=$ Spearman's correlation coefficient & *significant $(p<0.05)$
\end{tabular}

In the variable of service quality, the correlation coefficient of its subvariabel from the strongest to the weakest order was price and cleanliness, respectively. This result showed that a service considered as having good quality when consumers are able to get meal in affordable price $(r=0,257 ; p=0.001)$ and with clean and hygienic packaging and cutlery $(r=0.133 ; p=0.001)$. The price of food in this study came out as the most important aspect for consumers in which $45 \%$ the subjects perceived the price of the food they bought as expensive (Table 2). This result is in agreement with the findings of a study among middle-class communities in Indonesia suggesting that before deciding to buy meals at restaurant, initially they will weigh the amount of financial resources they should sacrifice to purchase the meals (Hatane et al., 2007). Because the price of food on train is above the average price of similar food in restaurants in the middle of the city, it can be understood if the consumer will have high expectations on this aspect and food price was found to be the main driving factor of consumer purchasing decisions. Cleanliness is the second most important aspect that affects satisfaction. When consumers encounter poor hygiene conditions, it is very difficult to overlook their negative experience in such cases. However, delivery time appeared to be not significantly correlated with satisfaction ( $r=0.004 ; p=0.752$ ). This was possible as train catering was able to serve meal to the consumers without long waiting by simply applying food assembly process on the train pantry whereas food preparation through cook and serves method had been performed in on-land kitchens. Service as part of product service has an abstract form (intangible) and also very complex (Sulek \& Hensley, 2004).

In the variable of food quality, the correlation coefficient of its subvariabel from the strongest to the weakest order was meal presentation, taste, and portion size, respectively. This result confirmed that the so-called good quality food product for consumers is the food which is served with appealing visual presentation to stimulate appetite $(r=0,261 ; p=0.001)$, has delicious flavor $(r=0.244 ; p=0.001)$, and has appropriate portion in accordance with consumer expectations $(r=0.211$; $\mathrm{p}=0.001$ ). Meal presentation in this study came out as the most important aspect for consumers in which $35 \%$ of the subjects perceived the meal presentation they received as poor (Table 2). This result 
INTERNATIONAL JOURNAL OF ACADEMIC RESEARCH IN BUSINESS AND SOCIAL SCIENCES

Vol. 10, No. 13, Special Issue: Upstream Research in Business and Management: Towards Socio-Economic Prosperity. 2020, E-ISSN: 2222-6990 @ 2020 HRMARS

corresponded with the findings of a study suggesting that before the consumers decide to eat, at first they will appraise the visual presentation of their dish when it is served (Ha \& Jang 2010). Portion size became the second most important aspect to influence satisfaction. Indonesian consumer character tends to emphasize the value of eating at an affordable price but able to get the appropriate portion, not too little but not too much (Gobel, 2008; Logiawan \& Subagio, 2014). Some passengers in this study explicitly mentioned since they have paid a high price for the foods on train, then the portion should be larger than what has been presented. The serving size was still too little according to their subjective observation. Finally, consumers would assess the dish by eating it. They would evaluate if the dish taste is matched to their individual taste (palatability) preferences. This aspect has been studied for a long time and experts agree that food taste is the most essential value that determines consumer satisfaction with food (Kivela et al., 2000). Many passengers in this study openly criticize the food served on the train that was still tasteless while they are keen to get a more seasoned food.

\section{Effect of Service and Food Quality on Passenger Satisfaction in Foodservice}

Linear regression analysis was performed to determine the effect of service and food quality simultaneously on passenger satisfaction, including the strength and direction. The results are presented in Table 3.

Table 3. Effect of Service and Food Quality on Passenger Satisfaction in Foodservice

\begin{tabular}{|c|c|c|c|c|}
\hline Model & $\mathrm{R}$ & $R^{2}$ & $\mathrm{~F}$ & $p$-value \\
\hline 1 & 0.422 & 0.178 & 2.744 & $0.018^{*}$ \\
\hline \multicolumn{5}{|c|}{$\begin{array}{l}\text { *p-value<0.05: model } 1 \text { explains a significant amount of the variance in customer } \\
\text { satisfaction }\end{array}$} \\
\hline \multicolumn{5}{|c|}{ Model 1} \\
\hline Indepel & iable & Coefficient (ß) & $\mathrm{t}$ & $p$-value \\
\hline Constar & & 0.184 & 0.178 & 0.859 \\
\hline Deliver & & -0.042 & -0.207 & 0.837 \\
\hline Price (P & & 0.263 & 1.760 & 0.082 \\
\hline Cleanlir & & 0.105 & 0.685 & 0.496 \\
\hline Taste (1 & & 0.138 & 0.698 & 0.488 \\
\hline Meal $\mathrm{Pr}$ & $n(M P)$ & 0.423 & 2.373 & $0.020 *$ \\
\hline Portion & & 0.255 & 1.419 & 0.160 \\
\hline
\end{tabular}

*significant $(p<0.05)$

Based on model 1 , it is observed that service and food quality has a simultaneous positive effect toward passenger overall satisfaction $(R=0.422 ; p<0.05)$. Significant $p$-value was also found in subvariable of meal presentation $(p<0.05)$, indicating that there was positive correlation with overall satisfaction of the subjects. This finding concurred with the study in airline context suggesting food quality as one of the important service quality factors in the economy class (An and Noh, 2009).

To calculate the effect of service quality and food quality on passenger satisfaction in this regression model, the R-square or Coefficient of Determination was used. Coefficient of determination $\left(R^{2}\right)$ according to the above analysis was 0.178 or equal to $17.8 \%$, which means that $17.8 \%$ of variability of passenger satisfaction can be explained by using variable of service quality and 
INTERNATIONAL JOURNAL OF ACADEMIC RESEARCH IN BUSINESS AND SOCIAL SCIENCES

Vol. 10, No. 13, Special Issue: Upstream Research in Business and Management: Towards Socio-Economic Prosperity. 2020, E-ISSN: 2222-6990 @ 2020 HRMARS

food quality by looking at the six factors. The remaining $82.2 \%$ of satisfaction variability should be explained by other causal factors originating outside this regression model. Study by Mahato (2011) suggested that the meal provision system for passengers during a good in-flight service flight needs to consider essential factors including production control, food distribution, service responsiveness by all employees, food menu control, and price control. This study may also support the concept of consumer perception proposed by Kwun (2011) and Ryu (2010); if the quality of food and service is improved and accompanied by the development of the type of menu offered and physical facilities of the restaurant, then it will surely increase customer satisfaction.

This study provides evidence that in long-distance train catering, the quality of food product and service had significant correlation with passenger satisfaction. Finding of our study might serve as the basis for further research in the field of food service and customer satisfaction particularly in the on-land transportation modes. To gain a more comprehensive knowledge on the food quality and service, we suggest measuring not only the six aspects concerned in this study but also other variables or indicators.

\section{Conclusion}

The quality of both food product and service of railway catering has proved to have positive effects on customer satisfaction. It was suggested for the operator of train catering to monitor the implementation of Standard Operating Procedure (SOP) in food production, especially the standard of spices to maintain taste of the dish and the completeness of foodstuffs including garnish to maintain the consistency of meal presentations from the beginning to the end of travel relation. Further studies need to address comprehensive aspects of food and service quality, for instances food hygiene and attitude of the personnel who serve the menu or food.

\section{Acknowledgement}

The authors are thankful to PT Kereta Api Indonesia railway company for the permission and cooperation to conduct all the procedures in this study.

\section{References}

An, M., \& Noh, Y. (2009). Airline customer satisfaction and loyalty: impact of in-flight service quality. Service Business, 3(3), 293-307.

Bei, L. T., \& Chiao, Y. C. (2001). An integrated model for the effects of perceived product, perceived service quality, and perceived price fairness on consumer satisfaction and loyalty. Journal of Consumer Satisfaction Dissatisfaction and Complaining Behaviour, 14, 125-140.

BPS-Statistics Indonesia. (2016). Land Transportation Statistics. Subdirectorate of Transportation Statistics - Statistics Indonesia, Jakarta. https://www.bps.go.id/publication/2017/11/27/500b5f875d5762ffb4e7a589/statistiktransportasi-darat-2016.html

Briginshaw, D. (2013). Train catering: Achilles' heel or unique selling point? Downloaded from http://www.railjournal.com/index.php/rolling-stock/train-catering-achilles-heel-or-uniqueselling-point.html.

Dimitra, T. (2014). The Views Of Preschool Students on The Issue of Quality of Education in Kindergartens: A Survey of "Infant Voices". Multilingual Academic Journal of Education and 
INTERNATIONAL JOURNAL OF ACADEMIC RESEARCH IN BUSINESS AND SOCIAL SCIENCES

Vol. 10, No. 13, Special Issue: Upstream Research in Business and Management: Towards Socio-Economic Prosperity. 2020, E-ISSN: 2222-6990 @ 2020 HRMARS

Social Sciences, 2(2), 59-85.

Frapin-Beaugé, A. J., Bennett, M. M., \& Wood, R. C. (1994). Some current issues in airline catering. Tourism Management, 15(4), 295-299.

Gobel, S. Y., Prawiningdyah, Y., \& Budiningsari, D. B. (2011). Menu pilihan diit nasi yang disajikan berpengaruh terhadap tingkat kepuasan pasien VIP di Rumah Sakit Umum Daerah Provinsi Sulawesi Tenggara. Jurnal Gizi Klinik Indonesia, 7(3), 136-145.

Ha, J., \& Jang, S. C. S. (2010). Effects of service quality and food quality: The moderating role of atmospherics in an ethnic restaurant segment. International Journal of Hospitality Management, 29(3), 520-529. http://dx.doi.org/10.1016/j.ijhm.2009.12.005.

Hatane, S., Kosasih, A. V., \& Novia, H. (2007). Perilaku Dan Keputusan Pembelian Konsumen Restoran Melalui Stimulus 50\% Discount Di Surabaya. Jurnal Manajemen Pemasaran, 2(2), 73-80.

James, J. (2005). Airline food: competing for the palates of passengers. Journal of Airline and Food Travel Service, 10(2), 15-17.

Jones, P. (1995). Developing new products and services in flight catering. International Journal of Contemporary Hospitality Management, 7(2/3), 24-28.

Jones, P. (2007) Flight-Catering, in Becker, H. And Grothues, U. (2006) Catering- Management Portrait einer Wachstumsbranche in Theorie und Praxis, Behr'sVerlag: Hamburg Chapter 1.4.1, 39-55.

Josiam, B. M., Malave, R., Foster, C., \& Baldwin, W. (2014). Assessing quality of food, service and customer experience at a restaurant: the case of a student run restaurant in the USA. Journal of Services Research, 14(1), 49-75.

Kivela, J., Inbakaran, R., \& Reece, J. (2000). Consumer research in the restaurant environment. Part 3: analysis, findings and conclusions. International Journal of Contemporary Hospitality Management, 12(1), 13-30.

Kwun, D. J. W. (2011). Effects of campus foodservice attributes on perceived value, satisfaction, and consumer attitude: A gender-difference approach. International Journal of Hospitality Management, 30(2), 252-261. http://dx.doi.org/10.1016/j.ijhm.2010.09.001

Law, R., \& Leung, R. (2000). A study of airlines' online reservation services on the internet. Journal of Travel Research, 39(2), 202-211.

Lemeshow, S. (1997). Besar Sampel dalam Penelitian Kesehatan. Yogyakarta: Gadjah Mada University Press.

Logiawan, Y., \& Subagio, H. (2014). Analisa Customer Value terhadap Customer Loyalty dengan Customer Satisfaction sebagai Variabel Intervening pada Restoran Bandar Djakarta Surabaya. Jurnal Manajemen Pemasaran Petra, 2(1), 1- 11.

Mahato, A. K. (2011). Assessing Satisfaction: A Study on International Passengers Using Nepal Airlines. AU Journal of Management, 9(1), 43-52.

Nathanail, E. (2008). Measuring the quality of service for passengers on the hellenic railways. Transportation Research Part A, 42, 48-66.

Oliver, R. L. (1980). A cognitive model of the antecedents and consequences of satisfaction decisions. Journal of Marketing Research, 17, 460-469.

Omar, M.B., Rahman, A.B.A, bin Abdul Hamid, F.Z. (2018). The Association between Corporate Governance and Disclosure of Audit committee Characteristics: A Conceptual Model for the Saudi Listed Companies, International Journal of Academic Research in Accounting, Finance and Management Sciences 8 (3): 325-335. 
Ryu, K., \& Han, H. (2010). Influence of the Quality of Food, Service, and Physical Environment on Customer Satisfaction and Behavioral Intention in Quick- Casual Restaurants: Moderating Role of Perceived Price. Journal of Hospitality and Tourism Research, 34(3), 310-329.

Sheeba, A. A., \& Kumuthadevi, K. (2013). Service Quality of South Indian Railway- Determinants of Passenger Satisfaction in Trains. International Journal of Business and Management Invention, 2(2), 49-54.

Sulek, J. M., \& Hensley, R. L. (2004). The Relative Importance of Food, Atmosphere, and Fairness of Wait: The Case of a Full-service Restaurant. Cornell Hotel and Restaurant Administration Quarterly, 45(3), 235-247.

Ueltschy, L. C., Laroche, M., Tamila, R. D., \& Yannopoulos, P. (2002) Cross-cultural invariance of measures of satisfaction and service quality. Journal Business Research, 57(8), 901-902.

WTO. (1985), Identification and Evaluation of those Components of Tourism Services which have a Bearing on Tourist Satisfaction and which can be Regulated, and State Measures to Ensure Adequate Quality of Tourism Services, World Tourism Organization, Madrid.

Zakaria, N. A., \& Abdullah, C. Z. H. (2018). Crowdsourcing and Library Performance in Digital Age. International Journal of Academic Research in Progressive Education and Development, 7(3), 127-136. 